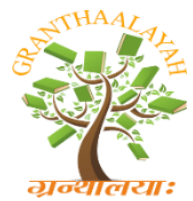

INTERNATIONAL JOURNAL OF RESEARCH GRANTHAALAYAH A knowledge Repository

Social

\title{
INDONESIAN GOVERNMENT APPROACHES AND POLICIES FOR RESOLVING PAPUA CONFLICTS
}

\author{
Payiz Zawahir Muntaha ${ }^{* 1}$, Virgie Delawillia Kharisma ${ }^{1}$, Margareta Hanita ${ }^{1}$ \\ ${ }^{* 1}$ School of Strategic and Global Studies, University of Indonesia, Indonesia
}

\begin{abstract}
Papua is a rich and beautiful land, which the wealth of natural resources is enhanced by the expanse of wild forests that are still green, blue sea and white sand beaches completing the beauty of the land of Papua. Nevertheless, Papua's land is always plagued by endless conflicts. Papua conflict is very complicated, the complexity of Papua conflict can be seen from the factors as well as the actors involved. This paper aims to explore the dimensions of the Papua conflict and the strategies undertaken by the Indonesian government to resolve it. The research method used in this study is a qualitative method, with a descriptive explanatory approach.
\end{abstract}

Keywords: Papua Conflict; Free Papua; Papua Development.

Cite This Article: Payiz Zawahir Muntaha, Virgie Delawillia Kharisma, and Margareta Hanita. (2019). "INDONESIAN GOVERNMENT APPROACHES AND POLICIES FOR RESOLVING PAPUA CONFLICTS." International Journal of Research - Granthaalayah, 7(12), 123-132. https://doi.org/10.29121/granthaalayah.v7.i12.2019.306.

\section{Introduction}

Papua is the easternmost region of Indonesia which joined the Republic of Indonesia Unitary through an international agreement, the New York Agreement on August 15, 1962 (Saltford, J : 2003) The region conflicts occur until this day both vertical conflicts between some Papuans and the Indonesian government as well as horizontal conflicts between communities in the land of Papua related to political issues (Kirsch, 2002 p53-79), economic or social culture (Bhakti \& Pigay, 2016, p18. Apart from that, the presence of other countries such as Australia are always involved and cannot be separated in conflicts that occur in Papua. The Australian government has openly supported the independent Papua of Indonesia. (Gietzelt, 1989, p201-221)

In 1998-2001 there was a shock of conflict in Papua which was called the phenomenon "The Papuan spring" (Chauvel : 2011). So as a response and solution to the problem, the Indonesian government under the leadership of President Megawati established Law No. 21/2001 concerning Papua's Special Autonomy. This is evidence of the seriousness of the Indonesian government to make Papua a priority in development (UU No. 21/2001). 
However, conflicts in Papua are always happening, the latest incident that shocked Indonesia was the massacre by the Papuan Armed Criminal Group (KKB) of 31 PT Istaka Karya employees in Nduga Regency, Sunday, 2 December 2018. Indeed this has become a very serious problem for the Indonesian government; bearing in mind the workers who are attacked are those who are working to build government projects to accelerate the development of Papua's land. Considering the facts above, this paper aims to discuss the Papua conflict from the perspective of the causes, actors and their impact on Indonesia in the International World.

\section{Research Method}

The research method used in this study is qualitative method (Denzin \& Lincoln : 1994), with a descriptive explanatory approach (Silalahi \& Atif : 2015). This approach is considered relevant to the problem under study. Then to analyze the facts found in the field, the steps are as follows: First, data reduction, i.e. compiling the data obtained, then determining the data under this study with classification. While less relevant data is ruled out. Second, from the important and relevant data complexities above, then the classification of data is carried out in several pressure points by the research. Third, qualitative data processing is performed. In this stage, each data is given an understanding so that it is easy to understand. This understanding is intended to analyze the core thoughts that are in the data.

\section{Papua Conflict Map}

The theory used is, what is called Arnold J. Toynbee "Challenge and Response" that every behavior is essentially feedback or response to stimuli (stimulus), because stimuli affect behavior, or even determine behavior (Arnold J. Toynbee: 1956, p271). This theory explains that all forms of actions were carried out by the Indonesian military and police will be against by the independent Papua organization (OPM).

Another theory is the Diadik Conflict Theory (Micro) put forward explicitly by George Simmel on the subject of conflict which is generally caused by problems concerning the honor, the existence of individuals and groups, which if they feel harmed their dignity and honor then often conflicts cannot be avoided and they are trying to defend themselves to maintain their existence in the community, and for this it often causes the Freeport conflict (Arifin Noor: 1997, p232). This theory is to explain the conflicts or disputes faced by independent Papua organization (OPM) with the government.

Political approach, which is used to analyze the interests of individuals and even groups concerning economic, social, cultural, and issues politics, where it allows a person or group to get an opportunity and show how their authority in mobilizing followers, collective decision making and the emergence of conflicts between groups.

The international characteristics or dimensions of the Papua case are determined by the role of state actors and non-state actors who have consistently and continuously "internationalized " Papuan issues, for example through lobbying and diplomacy, both of which are carried out by The Government of Indonesia and other parties opposed to the Government of Indonesia, including the Free Papua Organization (OPM) and several members of the Papua Council Presidium (PDP). 


\section{Local Dimension}

\section{The Demands of Independence in Various Cities in Papua and Issues of Injustice in Development}

Social justice for all Indonesian people will always maintain the unity and integrity of the unitary state of the Republic of Indonesia from Sabang to Merauke. Injustice and inequality of development have slowly eroded the nationalism of the younger generation in Papua, as Sabara believes there has been a "Split of Nationalism" among the younger generation of Papuans (Sabara, 2018, p1-18).

Papuan nationalism exists because of the various realities that appear to be ruled out. Papua's nationalism is not recognized even it is often considered illegitimate nationalism (Rozi, S . 2016, p75-84). At least this is proven by the re-emergence of Nationalism with the slogan "NKRI Price of Death" alleviate the reason and the meaning of liberation. So that the presence of Papuan nationalism becomes a real enemy of this type of nationalism without seeing what is developing Papuan nationalism. Extermination of Papuan nationalism by Indonesia continues to this day and who knows how long (Taum, 2015, p1).

\section{Issue Justification of the History of Integration in the 1960s}

One of the root causes of why Papua continues to be turbulent is the debate about the implementation of the Papua Referendum through the Determination of People's Opinion (PEPERA) in 1969. Many young Papuans do not fully understand why PEPERA must be held. This political event is what distinguishes the history of Papua's integration with other regions. In its history, although Indonesia had proclaimed its independence from Sabang to Merauke on August 17, 1945, the Dutch remained stubborn, unwilling to leave Papua (Pamuji, R.: 2018).

\section{International Dimension}

\section{Pressure on Human Rights Issues}

International support for pro-independence groups in Papua creates serious complexity for the Indonesian Government in diplomacy with foreign parties. Although the Government of Indonesia has strong political legitimacy (legal sovereignty) in Papua, Indonesia's bargaining position is weak when dealing with the international community about issues of democratization, human rights (HAM) and the environment in Papua (Brundige, E : 2004. In the research of S Rees who wrote about human rights violations (Rees, S.,2007, p637-639), health problems (Rees, S., 2013, p 280) as well as security issues in Papua (Rees, S. J. 2008, p641-).

Internationalization efforts to attract international attention or support the independence of Papua, began in 1962. As a form of resistance to the 1962 New York Agreement (NYA) which recognized the entry of Papua into the territory of the Republic of Indonesia (RI). The Papuan independence movement has had a great opportunity since the reformation in Indonesia began in mid-1998, where pro-independence groups (and pro-democracy groups in Papua) were more courageous and open in expressing their political demands. Especially with the release of the territory of East Timor from Indonesia and becoming an independent state in 1999. Then the political events became a new spirit for the struggle of OPM to make Papuan independence (Ramos-Horta, J. : 1987). 


\section{The Certainty of Freeport Indonesia}

The existence of PT Freeport in Bumi Papua makes the United States government have an interest in Bumi Papua (Hills, J., \& Welford, R. 2006, p108-114). The US government plays an important role in the conflict in Papua. The position or role of the US is difficult to separate from the long history and political process in Papua (Kyriakakis, J.: 2005, p95). According to John Roberts, the US-supported Indonesia's policy to "restore" the territory of Papua through diplomacy and in support of the Act of Free Choice in 1969 which later gave birth to a UN decision stating that Papua was part of Indonesian territory (Webster, D. 2013, p9-24).

\section{Social Networks and Papua Diaspora Raises the Issue of Free Papua}

Students and workers from Papua who study and work abroad become one of the important actors in campaigning for the Free West Papua movement (Webb-Gannon, C. 2014, p353-367). For example, in an event held by the Indonesian New Zealand Student Association held a public discussion titled Papua Today in Wellington, New Zealand, Monday (7/31/2018). The forum was held at Victoria University of Wellington (VUW) which was attended by two opposing camps related to the issue of Free Papua ( https://internasional.kompas.com ).

The problem of Papua has been the center of attention of several groups in New Zealand in recent years. Some of these groups such as the Peace Movement Aotearoa and the Maori Student Association and Pasifika Students. They accused the Indonesian government of deliberately discriminating and leaving Papua. Some even believe that Papuans still consistently live under military rule. Reconciliation, according to them, about the dark history in the past was never sought by the Indonesian government. This is a warning to the Indonesian government to provide intensive guidance related to nationality and Pancasila to Papuan students and workers who live abroad.

\section{Discussion of West Papua Issues in the 46th Pacific Islands Forum (Pif) Leaders Communiqué in Port Moresby, Papua New Guinea.}

Pacific Islands Forum (PIF) was established in 1971 under the name South Pacific Forum (SPF). PIF member countries include 16 countries namely: Australia, Cook Islands, Federated States of Micronesia, Fiji, Kiribati, Marshall Islands, Nauru, Niue, Palau, Papua New Guinea, Samoa, New Zealand, Solomon Islands, Tonga, Tuvalu, Vanuatu. Besides the permanent members, PIF has 13 dialogue partners, namely: the United States, China, the Philippines, India, Indonesia, Britain, Japan, Canada, Korea, Malaysia, France, Thailand, and the European Union. Indonesia has been a PIF dialogue partner since 2001.

The Pacific Islands Forum has just held its 46th annual meeting on September 7-11 2015 in Port Moresby, Papua New Guinea. Country leaders in the Pacific discuss the Papua issue and make decisions to help resolve the Papua problem. In the 2015 PIF communique, it was revealed that they recognized and respected Indonesia's sovereignty over Papua, but at the same time expressed concern over human rights violations in Papua. They then assigned the PNG PM to consult with Indonesia about the formation of a fact-finding team (TPF) involving various parties to review the human rights situation in Papua.

Before the PIF meeting, all non-governmental organizations (NGOs) in the Pacific region who were members of the Pacific Islands Association of Non-Governmental Organizations discussed 
specifically the human rights situation in Papua. They see Papuans as fellow Pacific people and therefore the problem of Papua is seen as their problem too. They showed solidarity by raising the issue of Papua in regional forums and conveying concerns and views about the human rights situation in Papua to three PIF leaders, namely the PIF leaders in 2014, 2015 and 2016.

The Papua problem enters the PIF through the Melanesian Spearhead Group (MSG), a subregional group of countries in the South Pacific whose members are PNG, Solomon Islands, Fiji, Vanuatu, and the Kanaky's community in New Caledonia. In the MSG summit in Honiara, Solomon Islands, in June 2015, the leaders of the MSG member countries accepted Papua-through the United Liberation Movement for West Papua (ULMWP)-as an observer member at the MSG. This new position makes it easier for ULMWP to bring the problem of Papua to all countries in the Pacific. Besides, with the full support of several state leaders, within two months of being accepted as an observer of the MSG, the issue of Papua received tremendous attention throughout the Pacific region (Trask, H. K. 1990, p119).

PIANGO networking in Pacific Islands Coalition for West Papua (PCWP) countries, as follow:

\begin{tabular}{|c|c|c|}
\hline Negara & NGO & Key Strategic Area \\
\hline Vanuatu & $\begin{array}{l}\text { Vanuatu Association of } \\
\text { NGOs - VANGO }\end{array}$ & $\begin{array}{l}\text { Community networks and advocacy (dominant } \\
\text { isu Free West Papua) }\end{array}$ \\
\hline $\begin{array}{l}\text { Solomon } \\
\text { Islands }\end{array}$ & $\begin{array}{l}\text { Development Service } \\
\text { Exchange - DSE }\end{array}$ & $\begin{array}{l}\text { Sustainable communities, quality of life, advice } \\
\text { to policymakers }\end{array}$ \\
\hline Tonga & $\begin{array}{l}\text { Civil Society Forum of } \\
\text { Tonga - CSFT }\end{array}$ & $\begin{array}{l}\text { Capacity Building and Institutional } \\
\text { Development }\end{array}$ \\
\hline Tuvalu & $\begin{array}{l}\text { Tuvalu Association of } \\
\text { NGOs - TANGO }\end{array}$ & $\begin{array}{l}\text { Healthy and sustainable development, } \\
\text { sustainable human development particularly in } \\
\text { outer- islands. }\end{array}$ \\
\hline Nauru & $\begin{array}{l}\text { Nauru Island Association of } \\
\text { NGOs - NIANGO }\end{array}$ & \\
\hline $\begin{array}{l}\text { Marshal } \\
\text { Islands }\end{array}$ & $\begin{array}{l}\text { Marshall Islands Council of } \\
\text { NGOs - MICNGOS }\end{array}$ & Climate Change, Coastal Management \\
\hline
\end{tabular}

\section{Indonesian Government's Approach and Policy for Papua}

The Government of Indonesia has taken various approaches and policies to reduce and resolve the Papua conflict. According to military strategist David Killculen, the issue of separatism is a variant of counter-insurgency warfare that needs to be addressed through military and non-military channels precisely and continuously (Kilcullen, D. J. 2005, p597-617). One of the most important non-military aspects is winning the sympathy of the local people (neutral population) and diverting their support from the OPM.

In the military field, the sympathy of the local community towards the Government will weaken the OPM support base, which has an impact on the KKB's limited access to intelligence, logistical information, and new members. Besides, community support also plays a large role in eliminating the space for OPM to hide by mixing amid civil society. On the other hand, in terms of politics, the form of the struggle of the OPM has been transformed in a direction that focuses on the path 
of diplomacy to gain legitimacy from other countries. Papuan community support will also be very useful in gaining international support for the position of the Indonesian government.

For this reason, the Government of Indonesia needs to ensure that the majority of the people support Papua and West Papua to remain part of the Republic of Indonesia. After the Reformation Era, the Government of Indonesia tried to diversify its approach to Papua, so that the presence of the government there was not dominated by a militaristic approach. The government is aware that the recurrence of the issue of human rights violations in the past will be a weakness that has cornered the government's position in the Papua region.

The policies and approaches decided by the Indonesian government for Papua are as follows:

\section{Implementation of the Papua Special Autonomy Law (Dana Otsus)}

UU no. 21/2001 on Papua Special Autonomy which has been discussed since the administration of president Abdurahman Wahid in 2001 and was established during the Megawati administration. Then in the Susilo Bambang Yudhoyono administration in 2004-2014, there were several rules passed including Presidential Instruction No. 5/2007 concerning the Acceleration of Development in Papua and West Papua. Presidential Regulation No. 65/2011 concerning the Papua Development Acceleration. Presidential Regulation 66/2011 concerning the Papua and West Papua Development Unit (UP4B). Presidential mandate No. 53/2014 concerning the Draft Bill on Special Autonomy for the Provinces in the Land of Papua

\section{RPJMN 2015-2019 with Focus on the Development of Indigenous Areas of Papua}

This change in development patterns is stated in Presidential Regulation No. 2/2015. The change in the sociological-anthropological-based approach to technocratic planning is in line with the basic idea of the Papua Governor Luke Enembe who is rearranging regional development in Papua.

Speaking of customary territories in the Land of Papua, we need to know its history when this concept began to be known and used and what indicators are used to classify tribes in Papua into the region. Based on data from the Papua Customary Council (DAP) (Timmer, J. 2008, p. 23-38). Uncen Anthropology, IL and the Culture Office in 2008, when compiling and making the Ethnic Mapping in the Land of Papua, the concept of Indigenous territories or culture areas had been known by Indigenous people in Papua Land since the 1960s, where this concept was an amalgamation of several pre-existing concepts by both the Dutch government and Western Anthropologists such as; Distribution of 6 Administrative Areas by the Dutch Government, Provincial Culture by GJ Held, Artistic Areas by Wingert, Rapl Linton, A. Gerbrands and S. Koijman.

As for the Papuans themselves, they have known their territorial boundaries traditionally since their ancestors, so the indicators used to arrange the division of tribes in the Land of Papua into 7 Indigenous Territories are, such as similarity in aspects; kinship, marriage, customary rights, type of leadership, characteristics of Freeport Indonesia sik, Freeport Indonesia's geography, and others. Papua Province is divided into five regions (while West Papua is only divided into two traditional regions, namely the Domberai area and the Bomberai customary area). The five indigenous territories of Papua referred to are arranged by name of the Regency with its capital cities: Mamta, Saereri, Anim Ha, La Pago, and Mee Pago. 
Presidential Instruction No 9/2017 concerning the Acceleration of Welfare Development In the framework of the Acceleration of Welfare Development in the Provinces of Papua and West Papua in the fields of health and education, local economic development, basic infrastructure, digital infrastructure, and connectivity to actualize a peaceful and prosperous Papua and West Papua Province community.

The construction of national roads in the Papua-West Papua Province from 2015 to 2018 has reached $1,982 \mathrm{~km}$. The $1,982 \mathrm{~km}$ of roads that have been built consist of $791 \mathrm{~km}$ in $2015,477 \mathrm{~km}$ in 2016, $345 \mathrm{~km}$ in 2017 and $369 \mathrm{~km}$ in 2018. While for road maintenance during the 2015-2018 period it is targeted to reach $14,367 \mathrm{~km}$. The $14,367 \mathrm{~km}$ of road length consists of 2,933 $\mathrm{km}$ in 2015, 3,625 km in 2016, 3,969 $\mathrm{km}$ in 2017 and 3,840 km in 2018.

At present, the Government has established the Bintuni Industrial Estate, Timika Industrial Estate, the Merauke Food Center Area (KEK Merauke), the Sorong Special Economic Zone (KEK) and other potential areas. Specifically, on August 1, 2016, President Joko Widodo ratified Government Regulation No. 31 of 2016 concerning Sorong Special Economic Zones (KEK). With this KEK framework, the Government is implementing several Freeport Indonesia scale and non-Freeport Indonesia scale incentives to accelerate investment in Sorong SEZ. Along with this regional policy, in 2014 - 2019, the Government paid attention to 25 Disadvantaged Regencies in Papua and 7 Disadvantaged Regencies in West Papua. Thus, this regional strategy links economically and strategically disadvantaged areas in various regions in the Land of Papua.

\section{Presidential Instruction No. 11/2017 regarding Papua PON 2020 Support}

President Jokowi looks serious in supporting Governor Lukas Enembe who is currently preparing Papua as the host of the 2020 National Sports Week (PON). This is reflected in the issuance of Presidential Instruction Number 10 of 2017 concerning Support for Organizing XX National Sports Week and XVI National Paralympic Week 2020 in Papua Province. In the Cabinet Session on July 19, 2017, President Jokowi stressed the need for legal protection to accelerate the construction of various facilities and infrastructure for PON 2020. After the discussion process since the end of July 2019, President Jokowi finally signed the Presidential Decree 10/2017 on December 18, 2017.

In President Jokowi's view, "The PON venue construction project in Papua has a very important meaning. Not only Papuan sports but also Indonesia". This was explained by President Jokowi when laying the first stone of the construction of the main stadium in Harapan Village, Jayapura, on May 9, 2015, last. The President's view is in line with the expectations of Governor Lukas Enembe, who sees the PON 2020 in Papua as an instrument of accelerating Papua's development and as an approach to building the identity and pride of the people of Papua. Sports, identity, and spirit of unity and oneness are put in one step.

\section{Divestment of PT. Freeport Share}

PT Freeport Indonesia has a Contract of Work (CoW) to commercialize minerals in the Grasberg and Ertsberg mining areas which began in 1967 and will only expire in 2021. Since Law No. 4 of 2009 concerning Mineral and Coal Mining (Minerba Law), the regulation regarding the exploitation of minerals and coal is in accordance with Pancasila and the 1945 Constitution, but 
because the Minerba Law is only able to reach legal actions after the issuance of the Minerba Law, something relating to existing work contracts before the Minerba Act was unreachable.

On the other hand, the existence of PT Freeport Indonesia's contract of work is deemed incompatible with Pancasila, namely the Fifth Principle "Social Justice for All Indonesian People" and Article 33 paragraph (3) of the 1945 Constitution concerning the substance of the earth, water, and natural resources "controlled by the state" and " used as much as the prosperity of the people " (Redi, A. 2016, p613-638).. This paper will discuss whether PT Freeport Indonesia's contract of work is under Pancasila and the 1945 Constitution? and how the Government's efforts to make PT Freeport Indonesia's contract of work under Pancasila and the 1945 Constitution.

Based on the author's analysis, PT Freeport Indonesia's Contract of Work contradicts Pancasila and the 1945 Constitution. Efforts to adjust PT Freeport Indonesia's work contract with Pancasila and the 1945 Constitution were carried out through the renegotiation of PT Freeport Indonesia's contract of work based on the principle of "hardship" in the UNIDROIT Principles of International Commercial Contracts (Perillo, J. M. 1994, p281), and the principle of natural resources for the national interest and for the welfare of the people in General Assembly Resolution resolution 1803 (XVII) of 14 December 1962, "Permanent Sovereignty Over Natural Resources" (Resolution, G. A. 1803).

Finance Minister Sri Mulyani and Minister Ignasius Jonan on August 29, 2017. There was an agreement reached, namely Freeport Indonesia agreed to divest $51 \%$ of shares to the Government of Indonesia, Freeport committed to building a smelter in 5 years until January 2022, changing the Contract of Work to a Business License Special Mining (IUPK), as well as Freeport Indonesia, have agreed to maintain greater state revenues than in the era of the contract of work regime.

\section{Higher Education Affirmation Program (ADIK) for Papuan Students}

The Higher Education Affirmation Program (ADIK) is a government partisanship program for native Papuan sons and daughters (OAP), to obtain tertiary education at PTN. The higher education affirmation policy for Papuan students provides access to higher education for Papuan students in reaching the best universities in Indonesia (Rivai, A. B. 2015, p266-287).. n 2019, a total of 777 native Papuans passed the State University through the Higher Education Affirmation (ADIK) program and attended 77 Universities in various cities in Indonesia. Since this program was implemented in 2012, 4,836 Papuan students have participated in this program.

\section{Conclusion}

The Land of Papua is a country that is rich and beautiful, rich in natural resources enhanced by expanses of wild and virgin wilderness, blue sea and white sand beaches perfect the beauty of the land of Papua. Nevertheless Papua's land is always plagued by endless conflicts. Papua conflict is very complex, the complexity of Papua conflict can be seen from the factors as well as the actors involved. This paper aims to explore Papua's conflict dimensions and the approaches and policies adopted by the Indonesian government to resolve them. The approach taken by the Indonesian government in reducing and resolving Papuan conflicts uses military and non-military approaches. The military approach was taken to reduce and prevent conflict situations from spreading and nonmilitary approaches were taken as an effort to build Papua for the better. Apart from that, the 
Indonesian government is also active in efforts to resolve the conflict in Papua in the international world.

\section{References}

[1] Arifin Noor, Ilmu Sosial Dasar (Bandung: Pustaka Setia, 1997), p232.

[2] Arnold J. Toynbee, A Study Of History (London: Oxford University Press, 1956), p271.

[3] Bhakti, I. N., \& Pigay, N. (2016). Menemukan Akar Masalah Dan Solusi Atas Konflik Papua: Supenkah?. Jurnal Penelitian Politik, 9(1), 18.

[4] Brundige, E., King, W., Vahali, P., Vladeck, S., \& Yuan, X. (2004). Indonesian Human Rights Abuses In West Papua: Application Of The Law Of Genocide To The History Of Indonesian Control. New Haven: Allard K. Lowenstein International Human Rights Clinic, Yale Law School.

[5] Butt, L., Djoht, D. R., Numbery, G., Peyon, A. I., \& Goo, A. (2010). Stigma and HIV/AIDS in highlands Papua. Pusat Studi Kependudukan-UNCEN.

[6] Chauvel, R. (2006, April). Australia, Indonesia and the Papuan crises. In Austral Policy Forum (pp. 06-14).

[7] Chauvel, R. (2011). Policy failure and political impasse: Papua and Jakarta a decade after the 'Papuan Spring'.

[8] Denzin, N. K., \& Lincoln, Y. S. (1994). Handbook of qualitative research. Sage publications, inc.

[9] Djafar, Z. (2016). Kemerdekaan Papua Dan Relevansi Reaksi Tiga Negara. Jurnal Penelitian Politik, 9(1), 18.

[10] Fernandes, C. (2006). Reluctant Indonesians: Australia, Indonesia, And The Future Of West Papua. Scribe Publications Pty Limited.

[11] Gietzelt, D. (1989). The Indonesianization Of West Papua. Oceania, 59(3), 201-221.

[12] Hills, J., \& Welford, R. (2006). Case Study: Auditing For Human Rights: Freeport-Mcmoran Copper And Gold In Papua. Corporate Social Responsibility And Environmental Management, 13(2), 108-114.

[13] Kilcullen, D. J. (2005). Countering global insurgency. Journal of Strategic Studies, 28(4), 597-617.

[14] Kirsch, S. (2002). Rumour And Other Narratives Of Political Violence In West Papua. Critique Of Anthropology, 22(1), 53-79.

[15] Kyriakakis, J. (2005). Freeport In West Papua: Bringing Corporations To Account For The International Human Rights Abuses Under Australian Criminal And Tort Law. Monash Ul Rev., 31,95 .

[16] Manurung, F., \& Iskandar, I. (2018). Upaya Badan Nasional Pengelola Perbatasan Dalam Menangani Masalah Keamanan Di Indonesia-Papua Nugini. Jurnal Online Mahasiswa (Jom) Bidang Ilmu Sosial Dan Ilmu Politik, 5(2), 1-15.

[17] Pamuji, R. (2018). Nasionalisme Papua Dalam Organisasi Aliansi Mahasiswa Papua.

[18] Papua, B. P. S. P. (2015). Papua dalam angka. BPS Propinsi Papua, 606.

[19] Payiz Zawahir Muntaha \& Wekke, I. S. (2017). Paradigma Pendidikan Islam Multikultural: Keberagamaan Indonesia Dalam Keberagaman. Intizar, 23(1), 17-40.

[20] Perillo, J. M. (1994). Unidroit Principles Of International Commercial Contracts: The Black Letter Text And A Review. Fordham L. Rev., 63, 281.

[21] Ramos-Horta, J. (1987). Funu: the unfinished saga of East Timor. The Red Sea Press.

[22] Redi, A. (2016). Kontrak Karya Pt Freeport Indonesia Dalam Perspektif Pancasila Dan Uud Nri 1945. Jurnal Konstitusi, 13(3), 613-638.

[23] Rees, S. J., Van De Pas, R., Silove, D., \& Kareth, M. (2008). Health And Human Security In West Papua. Med J Aust, 189(11-12), 641-3.

[24] Rees, S., \& Silove, D. (2007). Speaking Out About Human Rights And Health In West Papua. The Lancet, 370(9588), 637-639. 
[25] Rees, S., Silove, D. M., Tay, K., \& Kareth, M. (2013). Human Rights Trauma And The Mental Health Of West Papuan Refugees Resettled In Australia. Med J Aust, 199(4), 280-3.

[26] Rivai, A. B. (2015). Kebijakan afirmasi pendidikan tinggi untuk Papua. CosmoGov: Jurnal Ilmu Pemerintahan, 1(2), 266-287.

[27] Rozi, S. (2016). Nasionalisme, Demokratisasi, Dan Sentimen Primordialisme Di Indonesia: Problematika Identitas Keetnisan Versus Keindonesian Pada Studi Kasus Aceh, Papua, Bali, Dan Riau. Jurnal Penelitian Politik, 6(1), 75-84.

[28] Sabara, S. (2018). Split Nasionalisme Generasi Muda Papua Di Kota Jayapura: Perspektif Teori Identitas. Jpp (Jurnal Politik Profetik), 6(1), 1-18.

[29] Saltford, J. (2003). The United Nations and the Indonesian takeover of West Papua, 1962-1969: the anatomy of betrayal. Routledge.

[30] Silalahi, U., \& Atif, N. F. (2015). Metode Penelitian Sosial Kuantitatif.

[31] Supriyono, J. Orang Papua Dalam Pandangan Negara. Kata Pengantar, 59.

[32] Taum, Y. Y. (2015). Kekerasan Dan Konflik Di Papua: Akar Masalah Dan Strategi Mengatasinya. Jurnal Penelitian, 19(1).

[33] Tebay, N. (2005). West Papua: The Stuggle For Peace With Justice. Ciir.P6

[34] Timmer, J. (2008). Spectres of Indonesianisation and secession in Papua. In Papers presented at the Seminar on The Act of Free Choice, Institute of Netherlands History, The Hague (pp. 23-38).

[35] Trask, H. K. (1990). Politics in the Pacific Islands: Imperialism and native self-determination. Amerasia Journal, 16(1), 119.

[36] Wanandi, J. (2002). Indonesia: A Failed State?. Washington Quarterly, 25(3), 135-146.

[37] Webb-Gannon, C. (2014). Merdeka In West Papua: Peace, Justice And Political Independence. Anthropologica, 353-367.

[38] Webster, D. (2013). Self-Determination Abandoned: The Road to the New York Agreement on West New Guinea (Papua), 1960-62. Indonesia, (95), 9-24.

\footnotetext{
*Corresponding author.

E-mail address: faizzawahir19@gmail.com
} 